\title{
The Eurasian Economic Union Customs' Administration Mechanism in the Digital Era
}

\author{
N.G. Vovchenko ${ }^{1}$, O.B. Ivanova ${ }^{2}$, A.F. Khapilin ${ }^{3}$, S.A. Khapilin ${ }^{4}$
}

\begin{abstract}
:
Purpose: The aim of the article is to identify the prospects for the Eurasian Economic Union (EEU) customs regulation mechanism in digital transformation following the global trend.

Design/Methodology/Approach: For the purpose of determining priorities for the EEU customs mechanism digitization, it is necessary to define the regulatory framework on which the digitalization process is based, to analyze the customs' regulation sphere digitization direction in the member states of the EEU and to formulate the priorities for improving the EEU customs' regulation mechanism on the information and communication technologies.

Findings: EEU customs' regulation mechanism digitization key areas have been identified, based on the provisions of the EEU's Digital Agenda and the Declaration on further development of integration processes within the Union.

Practical implications: The results can be implemented in the Eurasian Economic Commission management practice, the EEU member states customs' authorities in order to improve the customs regulation mechanism.

Originality/Value: The main contribution of this study is to identify the differences in the customs regulation sphere digitization processes in the EEU member states and to identify the areas for implementing a unified strategy.
\end{abstract}

Keywords: Eurasian Economic Union, customs administration, digital transformation.

JEL Codes: G28, G38, F02, F15.

Paper Type: Research paper.

\footnotetext{
${ }^{l}$ Doctor of Economics, Professor, Professor, Department of Finance, Rostov State University of Economics, nat.vovchenko@gmail.com

${ }^{2}$ Doctor of Economics, Professor, Professor, Department of Finance Rostov State University

of Economics, sovet2-1@rsue.ru

${ }^{3}$ Candidate of Geological and Mineralogical Sciences, Associate Professor, Associate

Professor at the Department of International Trade and Customs, Rostov State University of

Economics, khapilin@mail.ru

${ }^{4}$ Doctor of Economics, Associate Professor, Associate Professor at the Department of

International Trade and Customs, Rostov State University of Economics, khapilin-

sa@mail.ru
} 


\section{Introduction}

The digital technologies development level is of crucial importance in addressing the issues of ensuring the countries and economic unions' competitiveness at the present stage of the world economy development. Digital economy is the driving force behind accelerating global economic development, increasing productivity, creating new markets and industries. It also opens the new opportunities for sustainable economic growth. The economic development of significant acceleration is achieved by those countries and economic associations that systematically build the leadership foundations and mechanisms in the digital economy.

Not only national governments, but also international organizations pay great attention to digital transformation issues such as: The United Nations, the World Trade Organization, the World Customs Organization, the World Bank and others. The countries cooperate in developing and improving the ICT use in the regional integration associations framework as well, including the Eurasian Economic Union.

The large-scale system program launched for the EEU customs' regulation mechanism digital development fully correlates with global trends and is aimed at qualitative transformational changes in the field of science and technology, artificial intelligence, creation of large data processing systems. Big data is a technology for the accumulation, processing and storage of large amounts of heterogeneous information. They are the basis for the development of machine learning algorithms and artificial intelligence, solving analytical problems and optimizing business processes. As this technology develops, the economic interrelations of people, the nature of the products and services sold, the channels of interaction between customers and suppliers are subject to significant transformations (Vovchenko, Ivanova, Andreeva and Kostoglodova, 2018). The customs regulation new digital platform formation in the sphere of foreign economic activity becomes an objective necessity in the context of new requirements applying to communications, computing power, information system and services in the digital economy era.

\section{Theoretical, Informational, Empirical and Methodological Issues}

The customs' regulation processes of digitalization which is needed for the theoretical substantiation within the Eurasian Economic Union is associated with the formation of a new paradigm of economic development (Savina, 2018) aimed at increasing the citizens and business entities involvement in the digital space, the sustainable digital ecosystems formation, the creation of customs, transport and logistics infrastructure, providing the foreign economic activity interaction in the digital space. This will be facilitated by the e-government concept by the implementation of transport and other infrastructure objects, the informatization, the professional networks creation, the development of technologies that include a wide range of innovations as artificial 
intelligence, cloud computing and blockchain (Shamakhov, Koryagin and Kunteshev, 2018).

The relations' regulation core in connection with the information interaction and information technologies used for interstate interaction, as well as the provision of public services to EEU member states created integrated information systems and information technologies. The treaty on the Eurasian Economic Union laid the foundations for the integration processes information support in all the areas affecting the operation of Article 23 of the EEU Treaty; the Protocol on Information, Communication Technologies and Information Interaction within the EEU determined that information interaction during the implementation of common processes within the EEU is carried out using the EEU integrated information system, ensuring the integration of geographically distributed state information resources and information systems of authorized bodies, as well as the information resources and systems of the Eurasian Economic Commission.

The Eurasian Economic Commission ensured the creation of a basis for transferring control over the digital economy to the supranational level, for which the decision of the Supreme Eurasian Economic Council No. 12 on October 11, 2017 approved the main directions for implementing the digital agenda of the Eurasian Economic Union until 2025. The digital agenda's goal is to update the existing integration cooperation mechanisms within the framework of the EEU, taking into account the global challenges of digital transformation, ensuring high-quality and sustainable economic growth of the member states, including the accelerated transition of economies to a new technological structure, the formation of new industries and markets, the labor resources development, the economic development and the conditions for the formation of an acceleration process for the industries within the territory of EEU (Kolodnyaya, 2018).

The EEU digital space construction requires the "seamlessness" of economic processes. The EEU Customs Code of January 1st 2018, laid down strategic norms complying with the concept of "digital customs" set out in the Strategic Guidelines of the World Customs Organization in the field of information technologies in 2018 and allowing the EEU Digital Agenda's implementation in the field of customs regulation in terms of:

- transition to electronic document flow in the customs sphere (securing the electronic documents' legal significance, electronic digital signature use, electronic document management systems' introduction);

- introduction of electronic customs declaration with the transition to the system of automatic registration and automatic release of goods;

- using electronic preliminary information as a key factor in ensuring security, on the one hand, and facilitating the development of foreign trade, on the other; 
- the single window system introduction, which allows to receive all the necessary permits in electronic form from the competent authorities related to the foreign trade issues by a single system.

As regards the introduction of the electronic declaration in the EEU member states before the EEU Customs' Code, the situation varied from country to country due to the legally established alternatives to submit a declaration of goods - electronically or in paper form. Since January 1, 2018, the situation has changed because the electronic customs declaration has become mandatory, except for some strictly defined cases. In most of the EEU member states, the automatic registration technologies and the automatic release of the goods are actively developed. In the Republic of Belarus and the Russian Federation, the experiments to automatically register and automatically issue goods declarations for individual customs procedures are carried out.

The mandatory preliminary notification in the EEU was introduced for the road transport in 2012, for rail transport in 2014, for air transport in 2017, for water transport in 2019. This technology implementation in the EEU was carried out in accordance with the framework standards of the World Customs Organization, World Trade Security and facilitation in order to minimize the EEU member states customs' legislation violations risks, as well as to improve and speed of customs operations, the customs' control efficiency etc. In the EEU member states, special software products, automated systems and online services were developed to fill out and submit electronic preliminary information. In the Republic of Belarus, a special software product E-client was developed for the formation of a form of electronic preliminary information and its submission to the automated system of customs authorities. Today in the Republic of Belarus, filling out a form of electronic preliminary information is possible with an online service (individuals can also use a separate service).

A fundamentally new stage in the task implementation of providing information to customs and other regulatory authorities on the goods' cross-border movement is the goods labeling and traceability technology, which allows the controlling authorities and consumers to receive the most complete information about goods, their promotion, services rendered, and any subject turnover at all stages of production, processing, storage, movement and sale, promptly identify illegal and counterfeit products (Ivanova, Khapilin and Khapilin, 2018). A pilot project on labeling and traceability of goods based on the goods' digital platform of the EEU the tobacco and tobacco products was organized by the EEC Council to test the labeling technology at the EEU scale. This project will become a part of the digital goods traceability system in the EEU.

In terms of ensuring the information submission to the authorized bodies and the coordinated development of electronic forms of interaction between customs, other regulatory bodies and interested parties in 2014 at the state heads' level, the main directions for the "single window" mechanism development in the system of foreign 
economic activity regulation were approved. Active work on the single window system creation is carried out in three out of five EEU member states, Kazakhstan, Kyrgyzstan and the Russian Federation.

At the same time, the EEU Digital Agenda implementation in the field of customs regulation requires an integrated approach to solve the trade facilitation problems and the existing technologies optimization. The digitization of customs regulation and its core - the digital customs concept - should be actively developed due to the digital technologies transformative capabilities' growth, go beyond electronic commerce and include, in addition to the widespread use of information and communication technologies, big data processing, telematics, cloud technologies, blockchain for effective control over the supply chain of goods, coordinated border management, the formation of a sustainable single window system and interaction with foreign customs' administration (Balandina, Ponomarev and Sinelnikov-Murylev, 2019).

\section{Results}

Prospects and the need to improve customs' administration processes within the EEU Digital Agenda framework are defined by the Declaration on further development of integration processes within the Union, according to which the priority goal in the key direction "forming the territory of innovations and promoting scientific and technological breakthroughs" is to expand the digital technologies use in customs' regulation and other areas of economic activity state administration ensuring the EEU' effective functioning.

Digital technologies offer new opportunities to increase the speed at which the customs authorities make decisions as well as their quality. The next stage of improving digital state government is associated with data centering - the formation of public administration, decisions in which are increasingly based on objective data. First, it is the ability to use big data to identify problems, model solutions, monitor compliance with established requirements and assess the regulation effectiveness (Dobrolyubova, Yuzhakov and Efremov, 2019). Big data processing technologies allow revealing the new interrelations between various parameters and adapting measures of the state policy to the needs and characteristics of regulatory addressees, participants in foreign economic activities, individuals engaged in customs' activities and others.

The creation of a unified system for the digital data transfer and exchange is no less a significant direction of the EEU customs' regulation mechanism digitization. Creating a common information space implies ensuring the exchange of not only government data, but also the data from the private sector, i.e., between customs' authorities and individuals involved in the goods' cross-border movement. The basis for these processes harmonization on the EEU territory is the formation of a single electronic trust space, which will increase the EEU integrated information system efficiency, ensure the interstate data and electronic document exchange security and reliability. 
As a result of the cross-border e-trust space formation, it will be possible to provide the individuals and legal entities registered in the EEU countries with access to legally significant services not only in the EEU territory, but also in third countries that have entered into an agreement on accession to a single e-trust space by the use of national or universal access means. The prospects for the single electronic trust space formation in the EEU are directly related to:

- the development of draft laws regulating the trans-border trust space creation, development and operation;

- the uniform standards adoption in the field of data transmission and exchanges;

- the coordination of principles and rules for the identification of subjects in a digital format, in ensuring the national data identification systems interoperability;

- providing the EEU countries' citizens the ability to track and control the continued use of personal data posted by users on Internet;

- ensuring the EEU citizens personal data protection, processed by operators located both on the EEU territory and beyond.

The digital technologies for goods traceability are of fundamental importance in terms of improving the EEU customs' administration mechanism. The traceability system development in the EEU space will be facilitated by the development of a single geographic information system, which includes a geographic information system, cartographic services and is aimed at simplifying control over the products and goods transportation and traceability (Andreeva, 2018). The basis for the full launch of a single digital platform aimed at sharing geospatial data are:

- the EEU member states regulatory framework harmonization in the digital geodata exchange;

- securing the certified earth remote sensing data use as legally relevant in the EEU regulatory framework, as well as defining the basic principles of collecting, storing, processing and distributing geospatial data;

- development and implementation of technologies for processing earth remote sensing data in government agencies and state-owned companies on the EEU territory (Andreeva, 2018).

\section{Conclusions and Recommendations}

Digital economy is an interacting environment between people, enterprises and the state, as well as material objects, providing increased production efficiency and cost reduction based on the widespread information and communication technologies, automated process control systems, additive manufacturing, automation technologies for logistics operations etc.

In the world's transformation era, the new sources of growth are associated with the digital technologies use, the digital goods and service development. At the same time, 
the speed of their implementation by foreign countries indicates that the task of assessing the feasibility of embedding the EEU countries into digitalization processes is no longer relevant. The EEU faces the global task of shaping the economy of the future by reformatting the economic systems of the member states to digital standards.

Within the EEU digital transformation framework, the new opportunities for improving the customs' administration mechanism appears as:

- improving customs administration, improving the planning efficiency and monitoring the customs authorities' activities, maintaining foreign trade customs statistics, analyze large amounts of data by using predictive analytics;

- obtaining and processing customs information innovative methods such as satellite tracking, radio frequency identification, etc.;

- using artificial intelligence technologies into the customs control processes and the technical means and implementation;

- using the formation of digital trading platforms based on the single window system, providing the continuous trading process concept.

\section{References:}

Andreeva, L.V. 2018. Creating a system of traceability of goods in the Eurasian Economic Union: goals, prospects, organizational and legal basis. International Cooperation of Eurasian States: Politics, Economics, Law, No. 2, 70-78.

Balandina, G.V., Ponomarev, Yu.Yu., Sinelnikov-Murylev, S.G. 2019. Customs Administration in Russia: What Should Modern Procedures Be. Moscow, Publishing House "Delo", RANEPA, 100.

Dobrolyubova, E.I., Yuzhakov, V.N., Efremov, A.A. 2019. The digital future of state governance by results. Moscow, Publishing House "Business", RANEPA, 10-17.

EEU. 2018. The Digital Agenda of the Eurasian Economic Union until 2025: perspectives and recommendations. Overview, available at: http://www.eurasiancommission.org.

Ivanova, O.B., Khapilin, A.F., Khapilin, S.A. 2018. Prospects for improving the Russian system of customs regulation at the Eurasian economic integration development present stage. Financial Research, 3, 166-172.

Kolodnyaya, G. 2018. Digital economy: features of development in Russia. Economist, 4, 63-69.

Savina, T.N. 2018. Digital economy as a new development paradigm: challenges, opportunities and prospects. Finance and credit, 3(24), 579-590.

Shamakhov, V.A., Koryagin, P.A., Kunteshev, R.A. 2018. Blockchain technology as a factor in the global modernization of international customs regulation processes. Management Consulting, 6, 63-67.

Vovchenko, N.G., Ivanova, O.B., Andreeva, O.V., Kostoglodova, E.D. 2018. Conceptual Approach to the Development of Financial Technologies in the Context of Digitalization of Economic Processes. European Research Studies Journal, 21, Special Issue 2, 11-20. 